P-ISSN: 1978-7227 E-ISSN: 2615-3017

dol : https://doi.org/10.30598/barekengvol14iss2pp253-266 National Accredited in SINTA 3, Decree No.: 28/E/KPT/2019

\title{
SISTEM PENDUKUNG PENGAMBILAN KEPUTUSAN REKRUTMEN GURU MENGGUNAKAN LOGIKA FUZZY TAHANI
}

\author{
Supporting System of Decision Making of Teacher Recruitment \\ Using Tahani Fuzzy Logic
}

\author{
Yayan Eryk Setiawan ${ }^{1 *}$
}

${ }^{1}$ Prodi Pendidikan Matematika, Fakultas Keguruan dan Ilmu Pendidikan, Universitas Islam Malang Jl. Mayjen Haryono 193 Kec. Lowokwaru, Kota Malang, Jawa Timur 65144, Indonesia

\author{
e-mail: 1*yayaneryksetiawan@unisma.ac.id \\ Corresponding author*
}

\begin{abstract}
Abstrak
Salah satu upaya untuk mendapatkan guru yang kompeten di bidangnya adalah dengan melakukan proses rekrutmen guru berdasarkan empat kompetensi guru, yaitu kompetensi kepribadian, sosial, pedagogik, dan profesional. Akan tetapi, kendala dari proses rekrutmen guru yang sering dilakukan adalah subyektifitas pengambilan keputusan. Salah satu cara untuk mengatasi subyektifitas dalam perekrutan guru adalah dengan menggunakan logika fuzzy tahani. Penelitian ini bertujuan untuk mengetahui implementasi logika fuzzy tahani dalam sistem pendukung pengambilan keputusan penerimaan guru berdasarkan hasil tes keempat kompetensi guru. Penelitian ini terdiri dari tiga tahap. Tahap pertama adalah menentukan fungsi derajat keanggotaan dari nilai kompetensi kepribadian, sosial, pedagogik, dan profesional. Tahap kedua adalah mendesain program fuzifikasi tahani dengan menggunakan microsoft excel. Tahap ketiga adalah mengimplementasikan program fuzzy tahani yang berhasil dibuat untuk pengambilan keputusan penerimaan guru. Hasil penelitian menunjukkan bahwa pengambilan keputusan penerimaan guru yang menggunakan logika fuzzy tahani lebih baik daripada hanya menggunakan nilai rata-rata. Karena logika fuzzy tahani mempertimbangkan berbagai kriteria, sedangkan rata-rata hanya mempertimbangkan satu kriteria yang memiliki nilai tinggi.
\end{abstract}

Kata Kunci : Logika Fuzzy Tahani, Sistem Pendukung Pengambilan Keputusan, Rekruitmen Guru.

\begin{abstract}
One effort to get teachers who are competent in their fields is to conduct a teacher recruitment process based on four teacher competencies, namely personal, social, pedagogic, and professional competencies. However, the obstacle of the teacher recruitment process that often done is the subjectivity of decisionmaking. One way to overcome subjectivity in teacher recruitment is by using tahani fuzzy logic. For this reason, this study aims to determine the implementation of tahani fuzzy logic in the supporting system of decision making for teacher admissions based on the results of the four teacher competency tests. This research consists of three stages. The first stage is determining the function of the degree of membership from the value of personal, social, pedagogical, and professional competencies. The second step is designing the tahani fuzzification program using Microsoft Excel. The third stage is implementing the fuzzy tahani program that successfully created for the decision to make admissions. The results showed that teacher acceptance decision making using tahani fuzzy logic was better than just using an average value. Because tahani fuzzy logic considers various criteria, while the average only considers one criterion that has a high value.
\end{abstract}

Keywords: Tahani Fuzzy Logic, Supporting System of Decision Making, Teachers Recruitment. 


\section{PENDAHULUAN}

Berbagai sekolah melakukan usaha untuk mendapatkan guru yang kompeten di bidangnya melalui proses rekrutmen guru. Tujuan utama dari proses rekrutmen yaitu untuk mendapatkan orang yang tepat dan memenuhi persyaratan tertentu untuk mengisi posisi yang kosong, sehingga orang tersebut mampu bekerja secara optimal dan dapat bertahan di perusahaan untuk waktu yang lama [1]. Tujuan dari perekrutan guru adalah untuk mendapatkan guru yang kompeten dalam bidangnya agar bisa secara optimal dalam mendidik siswa. Salah satu kriteria untuk merekrut guru adalah berdasarkan empat kompetensi guru, yaitu: kompetensi kepribadian, kompetensi pedagogik, kompetensi profesional, dan kompetensi sosial. Hasil penelitian menunjukkan bahwa kompetensi pedagogik, profesional, sosial dan kepribadian memiliki pengaruh yang signifikan terhadap prestasi belajar siswa, dimana kompetensi guru berpengaruh secara langsung terhadap prestasi belajar sebesar 40,9\% [2]. Kompetensi guru juga akan mempengaruhi cara guru dalam mengajar di kelas, yang selanjutnya cara mengajar guru dapat mempengaruhi prestasi siswa [3], pemahaman siswa terhadap materi [4], [5], dan cara siswa dalam menyelesaikan masalah matematika [6]. Hasil penelitian juga menunjukkan bahwa cara mengajar guru yang kurang profesional dapat mengakibatkan siswa tidak menguasai suatu konsep dari materi yang sedang dipelajari [7], [8], [9]. Jadi penting bagi sekolah untuk merekrut guru yang kompeten di bidangnya.

Akan tetapi, kendala yang sering muncul dalam melakukan perekrutan guru adalah subyektifitas pengambilan keputusan, tidak adanya transparansi hasil penilaian untuk perekrutan, tidak memperhatikan standar kualifikasi, atau tidak melalui tahapan-tahapan perekrutan guru. Subyektifitas yang dimaksud yaitu orang yang sesuai dengan pimpinan atau saudara dekat pimpinan yang akan direkrut sebagai guru tanpa melihat kompetensi yang dimiliki guru tersebut. Subyektifitas biasanya terjadi untuk mengurangi kerumitan proses pengambilan keputusan akibat dari banyaknya alternatif yang harus dipilih [1]. Tidak adanya transparansi hasil penilaian artinya hasil penilaian tidak terbuka atau hanya terbatas pada orang tertentu saja. Ketidaktransparansi hasil penilaian ini biasanya dilakukan karena tes perekrutan hanya sebatas formalitas, dimana sudah ditetapkan calon yang akan direkrut. Tidak memperhatikan standar kualifikasi artinya tidak memperhatikan keahlian yang diperlukan untuk melakukan sesuatu atau untuk menduduki jabatan tertentu. Hal ini biasanya terjadi karena calon guru memiliki kedekatan dengan pimpinan. Tidak melalui tahapantahapan perekrutan guru ini biasanya dilakukan untuk menghindari kerumitan proses rekruitmen guru. Subyektifitas, ketidaktransparansi hasil penilaian, tidak memperhatikan standar kualifikasi, atau tidak melalui tahapan-tahapan perekrutan guru ini dapat mengakibatkan ketidakjelasan terhadap pengambilan keputusan, karena tidak mempunyai dasar yang kuat serta ketidakadilan terhadap pelamar kerja. Atau bahkan keempat masalah tersebut dapat mengakibatkan kesalahan dalam merekrut guru, karena tidak mempertimbangkan kompetensi-kompetensi yang dimiliki calon guru.

Salah satu cara untuk mengatasi masalah-masalah dalam perekrutan guru adalah dengan menggunakan logika fuzzy Tahani. Hasil penelitian menunjukkan bahwa pendekatan logika fuzzy Tahani dapat menghasilkan suatu informasi dari calon karyawan yang layak untuk direkrut, sehingga dapat digunakan sebagai sistem pendukung dalam perekrutan karyawan atau pegawai [1]. Selain itu, Logika fuzzy Tahani dapat diterapkan untuk mengevaluasi kinerja karyawan dengan menggunakan nilai dari kriteria-kriteria kinerja karyawan sebagai data input. Proses evalusi kinerja karyawan yang dilakukan dengan logika fuzzy Tahani menjadi lebih adil dan akurat dengan memperhatikan nilai yang proporsional bagi setiap kriteria yang digunakan. Logika fuzzy Tahani dapat dijadikan sebagai alat bantu pendukung keputusan dalam melakukan evaluasi kinerja karyawan [10]. Jadi logika fuzzy Tahani secara umum dapat digunakan sebagai sistem pendukung pengambilan keputusan, termasuk pengambilan keputusan rekrutmen guru.

Penelitian sebelumnya tentang implementasi fuzzy Tahani sebagai sistem pendukung pengambilan keputusan telah banyak dilakukan. Misalnya fuzzy Tahani digunakan untuk perekrutan pegawai tetap dimana variabel inputnya berdasarkan masa kerja, kehadiran, kedisiplinan, kinerja, dan kepribadian [1]. Penelitian lain tentang implementasi logika Fuzzy Tahani adalah untuk mengevaluasi kinerja pegawai, dimana variabel inputnya adalah kehadiran, kualitas kerja, kreatifitas, technical skills, communication skills, attitude [10]. Penelitian tentang implementasi Fuzzy Tahani juga digunakan sebagai sistem pendukung keputusan lulusan terbaik [11], sebagai sistem pendukung evaluasi kinerja guru, dimana variabel penilaian kinerja guru dilihat dari kepribadian, prestasi kerja, kerjasama, dan prakarsa [12], sebagai sistem pendukung untuk penentuan tunjangan terhadap pendidik dan tenaga kependidikan yang didasarkan pada usia, lama bekerja, TMT, sertifikasi dan gaji [13]. Logika Fuzzy Tahani juga digunakan sebagai sistem pendukung untuk menilai kinerja dosen berdasarkan kuisioner evaluasi belajar [14], digunakan sebagai sistem pendukung untuk penilaian kinerja instruktur yang sesuai standar yang dinginkan [15], dan dapat juga digunakan untuk sistem 
pendukung keputusan kenaikan jabatan [16]. Jadi secara umum logika fuzzy Tahani banyak digunakan untuk sistem pendukung pengambilan keputusan.

Berbeda dengan penelitian-penelitian yang telah dilakukan sebelumnya, penelitian ini merupakan implementasi Fuzzy Tahani sebagai sistem pendukung perekrutan guru tetap yayasan dimana variabel inputnya berdasarkan nilai kompetensi kepribadian, sosial, pedagogik, dan profesional. Jadi tujuan penelitian ini adalah untuk mengetahui hasil implementasi logika fuzzy Tahani sebagai sistem pendukung pengambilan keputusan dalam perekrutan guru. Hasil penelitian ini akan memberikan manfaat yaitu: diperolehnya calon guru yang memiliki kompetensi sesuai bidangnya, mengurangi subyektifitas dan kerumitan dalam perekrutan calon guru yang kompeten, dan memliki dasar pengambilan keputusan yang adil dalam merekrut guru.

\section{METODE PENELITIAN}

Penelitian ini merupakan penelitian terapan dari teori fuzzy tahani sebagai sistem pendukung pengambilan keputusan dalam perekrutan guru berdasarkan nilai dari keempat kompetensi guru, yaitu kompetensi kepribadian, kompetensi sosial, kompetensi pedagogik, dan kompetensi profesional. Soal-soal yang digunakan untuk menilai kompetensi guru tersebut merupakan soal pilihan ganda dengan total ada 90 soal yang terdiri dari: 15 soal tes kepribadian, 15 soal tes sosial, 35 soal tes pedagogik, dan 25 soal tes profesional. Objek penelitian ini adalah 18 peserta yang mengikuti tes masuk untuk menjadi guru tetap Yayasan di MTs Darun Najah kabupaten Lumajang yang membutuhkan guru Matematika sebanyak 3 orang. Kriteria calon guru yang akan diterima melalui perekrutan ini adalah memiliki nilai yang berada pada kategori tinggi dari masing-masing kompetensi guru. Penentuan kategori rendah, sedang, dan tinggi dari masingmasing nilai kompetensi guru dilakukan dengan menerapkan teori fuzzy tahani.

Prosedur penelitian ini terdiri dari tiga tahap (lihat Gambar 1), yaitu: 1) Menentukan fungsi derajat keanggotaan hasil tes kompetensi, 2) mendesain program Fuzzy Tahani dengan Microsoft Excel, 3) mengimplementasikan desain program Fuzzy Tahani.

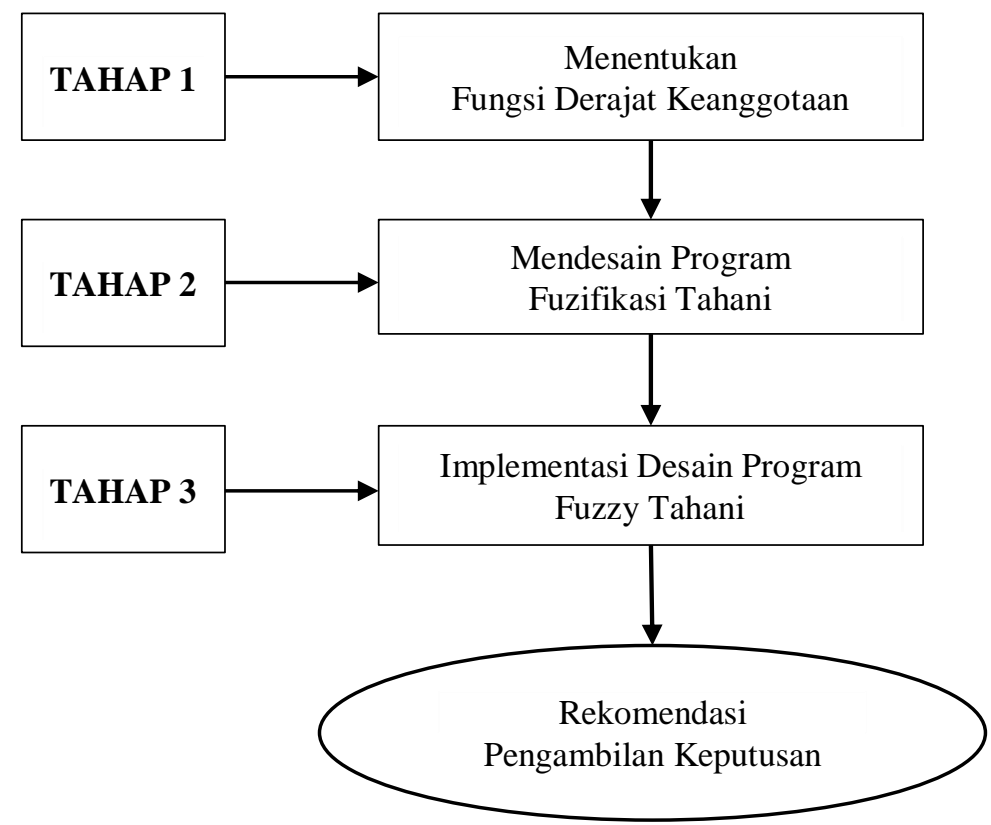

Gambar 1. Prosedur Penelitian

Dari Gambar 1 diperoleh tiga tahap penelitian ini. Tahap pertama adalah menentukan fungsi derajat keanggotaan dari masing-masing nilai kompetensi guru yang terdiri dari: kompetensi kepribadian, kompetensi sosial, kompetensi pedagogik, dan kompetensi profesional. Fungsi derajat keanggotaan adalah suatu kurva yang menunjukkan pemetaan titik-titik input data ke dalam nilai keanggotaannya yang memiliki interval antara 0 sampai 1 dinotasikan [0 1]. Langkah-langkah menentukan fungsi derajat keanggotaan, yaitu: 1) menentukan variabel input yang berupa nilai dari 4 kompetensi, 2) menentukan variabel output yang dibagi ke dalam tiga bagian, yaitu rendah, sedang, dan tinggi, dan 3) menentukan fungsi derajat keanggotaan yang ditentukan dengan representasi kurva linier, representasi kurva segitiga, dan representasi kurva trapesium. 
Representasi kurva linier digambarkan sebagai suatu garis lurus. Bentuk representasi linier ini merupakan bentuk sederhana yang mendekati suatu konsep fuzzy. Ada dua himpunan fuzzy linier, yaitu: 1) Linier naik, kenaikan derajat keanggotaan himpunan dimulai dari nilai domain yang memiliki derajat keanggotaan nol bergerak ke kanan menuju nilai domain yang memiliki derajat keanggotaan 1 (lihat Gambar 2.a). 2) Linier turun, penurunan derajat keanggotaan himpunan dimulai dari nilai domain yang memiliki derajat keanggotaan satu bergerak ke kanan menuju nilai domain yang memiliki derajat keanggotaannya nol (lihat Gambar 2.b).

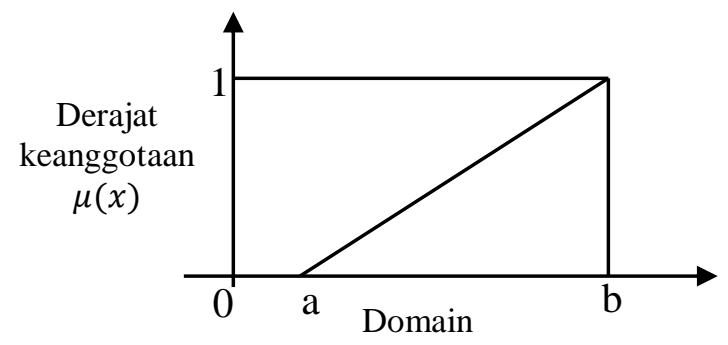

Gambar 2a. Linier Naik

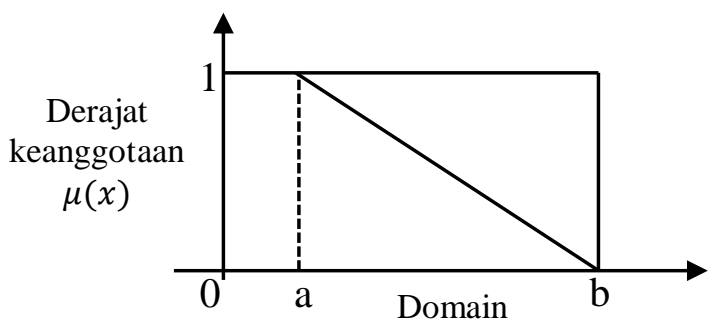

Gambar 2b. Linier Turun

Gambar 2. Representasi Kurva Linier

Fungsi untuk derajat keanggotaan dari linier naik dirumuskan berikut ini.

$$
\mu(x)=\left\{\begin{array}{cc}
0 & \text { jika } x \leq a \\
\frac{(x-a)}{(b-a)} & \text { jika } a \leq x \leq b \\
1 & \text { jika } x \geq b
\end{array}\right.
$$

Fungsi untuk derajat keanggotaan dari linier turun dirumuskan berikut ini.

$$
\mu(x)=\left\{\begin{array}{cc}
1 & \text { jika } x \leq a \\
\frac{(b-x)}{(b-a)} & \text { jika } a \leq x \leq b \\
0 & \text { jika } x \geq b
\end{array}\right.
$$

Representasi kurva segitiga merupakan gabungan dari representasi kurva linier naik dan kurva linier turun, representasi kurva segitiga dapat dilihat pada Gambar 3.

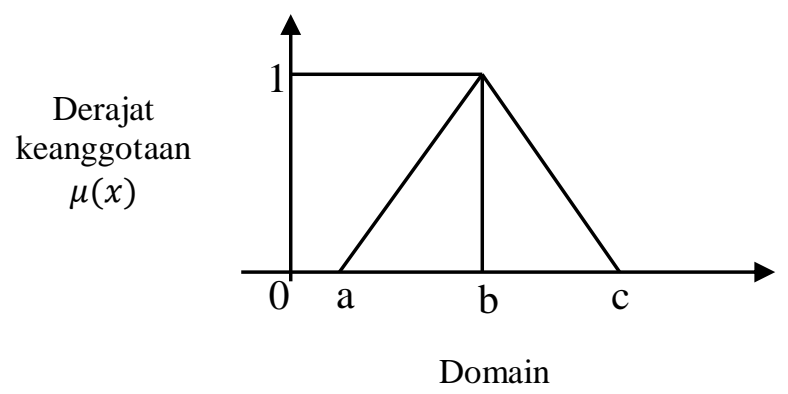

Gambar 3. Representasi Kurva Segitiga

Fungsi untuk derajat keanggotaan dari kurva segitiga dirumuskan berikut ini. 


$$
\mu(x)=\left\{\begin{array}{cc}
0 & \text { jika } x \leq a \\
\frac{(x-a)}{(b-a)} & \text { jika } a \leq x \leq b \\
\frac{(c-x)}{(c-b)} & \text { jika } b \leq x \leq c
\end{array}\right.
$$

Representasi kurva trapesium merupakan representasi kurva segitiga dengan beberapa titik (domain) memiliki derajat keanggotaan yang sama, representasi kurva trapesium dapat dilihat pada Gambar 4.

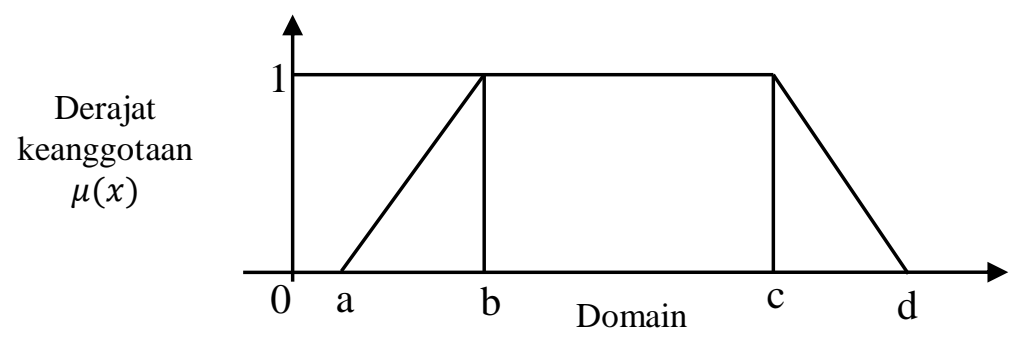

Gambar 4 Representasi Kurva Trapesium

Fungsi untuk derajat keanggotaan dari kurva trapesium dirumuskan berikut ini.

$$
\mu(x)= \begin{cases}0 \text { jika } x \leq \text { a atau } x \geq d \\ \frac{(x-a)}{(b-a)} & \text { jika } a \leq x \leq b \\ 1 & \text { jika } b \leq x \leq c \\ \frac{(d-x)}{(d-c)} & \text { jika } c \leq x \leq d\end{cases}
$$

Tahap Kedua adalah mendesain program fuzzifikasi Tahani yang dalam penelitian ini menggunakan program microsoft excel. Alasan peneliti menggunakan microsoft excel adalah dapat digunakan dalam data yang cukup besar, dapat digunakan untuk mendesain program Fuzzy Tahani, penggunaan microsoft excel lebih mudah dipahami oleh pengguna, dan program microsoft excel dimiliki oleh setiap orang. Ada 4 langkah untuk mendesain program fuzifikasi Tahani dengan Microsoft Excel, yaitu: 1) Membuat desain program penilaian kompetensi, 2) Membuat desain program derajat keanggotan dari masing-masing variabel input, 3) Membuat fuzifikasi keanggotaan dari semua variabel output, dan 4) Membuat desain program rekomendasi keputusan.

Tahap Ketiga adalah mengimplementasikan desain program Fuzzy Tahani yang berhasil dibuat untuk menentukan guru yang akan diterima sebagai guru Matematika di MTs Darun Najah Lumajang. Tahapantahapan implementasi yaitu: 1) Memasukkan skor tes kompetensi calon guru ke program yang telah berhasil didesain; 2) Melakukan fuzifikasi terhadap nilai yang diperoleh, dan 3) Menentukan rekomendasi keputusan.

\section{HASIL DAN PEMBAHASAN}

Sesuai dengan tahapan penelitian ini, maka diperoleh hasil penelitian dari masing-masing tahapan tersebut, yaitu fungsi derajat kenaggotaan, desain program fuzifikasi tahani yang menggunakan microsoft excel, dan hasil implementasi fuzzy tahani untuk perekrutan guru. Masing-masing dibahas berikut ini.

\subsection{Fungsi Derajat Keanggotaan}

Langkah pertama untuk menentukan fungsi derajat keanggotaan adalah menentukan variabel input yang berupa nilai dari 4 kompetensi, yaitu kompetensi kepribadian, sosial, pedagogik, dan profesional. Keempat kompetensi tersebut digunakan sebagai variabel input dari fungsi keanggotaan fuzzy. Setiap variabel input tersebut menggunakan fungsi dari kurva linier, kurva segitiga, dan kurva trapesium untuk memperoleh derajat keanggotaan dalam himpunan fuzzy. Nilai-nilai variabel input dalam penelitian ini menggunakan aturan umum, yaitu hasil tes terendah dan tertinggi yang dicapai oleh semua peserta tes. Langkah kedua adalah menentukan variabel output. Setelah variabel input dimasukkan ke dalam fungsi keanggotaan, maka diperoleh variabel output yang terdiri dari tiga bagian, yaitu rendah, sedang, dan tinggi. 
Langkah ketiga adalah menentukan fungsi derajat keanggotaan dari masing-masing kompetensi, yaitu berikut ini.

\subsubsection{Fungsi Derajat Keanggotaan Kompetensi Kepribadian}

Pada variabel output dari kompetensi kepribadian (KP) didefinisikan ada tiga himpunan fuzzy, yaitu rendah, sedang, dan tinggi. Penentuan derajat keanggotaan rendah menggunakan rumus fungsi kurva linier turun (2), untuk himpunan fuzzy sedang digunakan rumus fungsi kurva bentuk segitiga (3), untuk himpunan fuzzy tinggi digunakan rumus fungsi kurva linier naik (1). Hasil tes kompetensi kepribadian dari 18 calon guru diperoleh nilai minimal adalah 67 dan nilai maksimalnya adalah 87. Diperoleh nilai tengah dari 67 dan 87 adalah $(67+87) / 2=77$. Diperoleh nilai input untuk untuk kompotensi kepribadian, yaitu: rendah [0, 67, 77]; sedang [67, 77, 87]; dan tinggi [77, 87, 100]. Representasi dengan grafik untuk nilai input keanggotaan kompetensi kepribadian dapat dilihat pada Gambar 5.

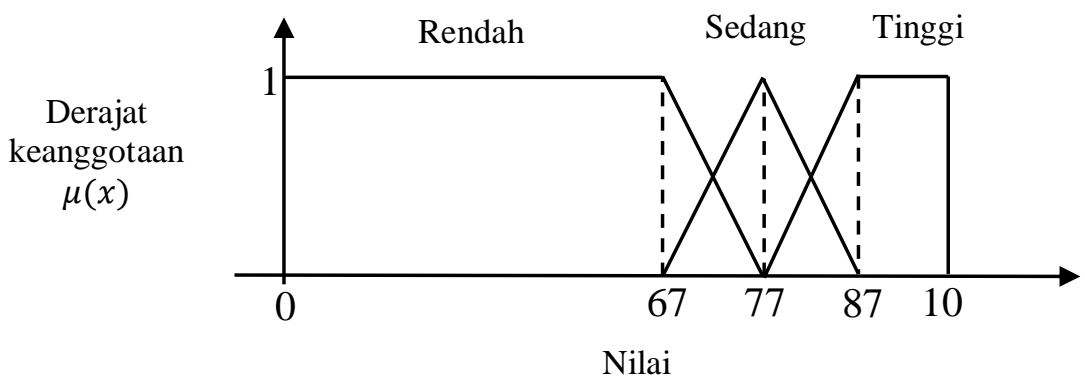

Gambar 5. Representasi Grafik Fungsi Derajat Keanggotaan Kompetensi Kepribadian berikut.

Rumus fungsi untuk masing-masing keanggotaan fuzzy untuk variabel kompetensi kepribadian sebagai

$$
\begin{aligned}
& \mu_{\text {rendah }}(x)=\left\{\begin{array}{cc}
1 & x \leq 67 \\
\frac{(77-x)}{(77-67)} & 67 \leq x \leq 77 \\
0 & x \geq 77
\end{array}\right. \\
& \mu_{\text {sedang }}(x)=\left\{\begin{array}{cc}
0 & x \leq 67 \text { atau } x \geq 87 \\
\frac{(x-67)}{(77-67)} & 67 \leq x \leq 77 \\
\frac{(87-x)}{(87-77)} & 77 \leq x \leq 87
\end{array}\right. \\
& \mu_{\text {tinggi }}(x)=\left\{\begin{array}{cc}
0 & x \leq 77 \\
\frac{(x-77)}{(87-77)} & 77 \leq x \leq 87 \\
1 & x \geq 87
\end{array}\right.
\end{aligned}
$$

\subsubsection{Fungsi Derajat Keanggotaan Kompetensi Sosial}

Dari variabel output Kompetensi Sosial (KS) didefinisikan tiga himpunan Fuzzy, yaitu rendah, sedang, dan tinggi. Representasi kurva untuk himpunan keanggotaan rendah menggunakan rumus fungsi kurva linier turun (2), representasi kurva untuk himpunan keanggotaan sedang menggunakan rumus fungsi kurva segitiga (3), sedangkan representasi untuk kurva himpunan keanggotaan tinggi menggunakan rumus fungsi kurva linier naik (1). Hasil tes kompetensi sosial dari 18 calon guru diperoleh nilai minimal adalah 67 dan nilai maksimalnya adalah 93. Diperoleh nilai tengah dari 67 dan 93 adalah $(67+93) / 2=80$. Diperoleh nilai input untuk untuk kompotensi sosial, yaitu: rendah [0, 67, 80]; sedang [67, 80, 93]; dan tinggi [80, 93, 100]. Representasi grafik fungsi keanggotaan kompetensi sosial dapat dilihat pada Gambar 6. 


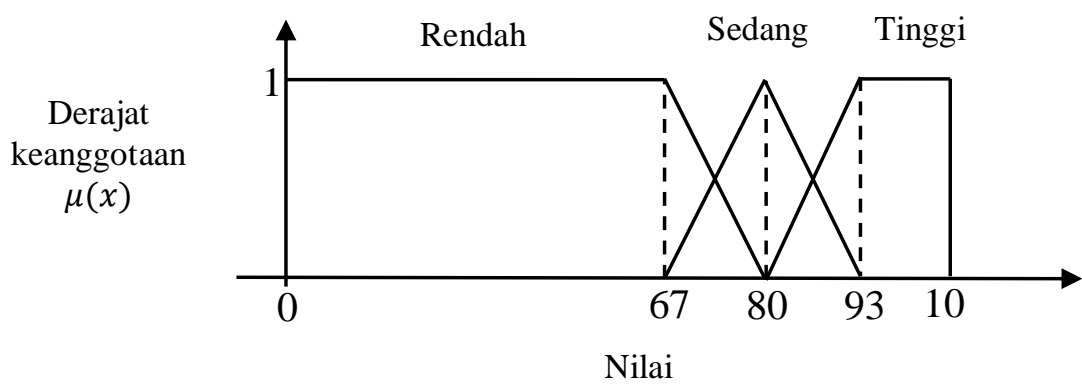

Gambar 6. Representasi Grafik Fungsi Keanggotaan Kompetensi Sosial

Rumus fungsi yang digunakan untuk menyatakan derajat keanggotaan dari variabel kompetensi sosial sebagai berikut.

$$
\begin{aligned}
& \mu_{\text {rendah }}(x)=\left\{\begin{array}{cc}
1 & x \leq 67 \\
\frac{(80-x)}{(80-67)} & 67 \leq x \leq 80 \\
0 & x \geq 80
\end{array}\right. \\
& \mu_{\text {sedang }}(x)=\left\{\begin{array}{cc}
\frac{(x-67)}{(80-67)} & x \leq 67 \text { atau } x \geq 93 \\
\frac{(93-x)}{(93-80)} & 80 \leq x \leq 80
\end{array}\right. \\
& \mu_{\text {tinggi }}(x)=\left\{\begin{array}{cc}
0 & x \leq 80 \\
\frac{(x-80)}{(93-80)} & 80 \leq x \leq 93 \\
1 & x \geq 93
\end{array}\right.
\end{aligned}
$$

\subsubsection{Fungsi Keanggotaan Kompetensi Pedagogik}

Pada variabel output dari Kompetensi Pedagogik (KP) didefinisikan tiga himpunan Fuzzy, yaitu rendah, sedang, dan tinggi. Representasi kurva untuk himpunan keanggotaan rendah menggunakan rumus fungsi kurva linier turun (2), representasi kurva untuk himpunan keanggotaan sedang menggunakan rumus fungsi kurva segitiga (3), sedangkan representasi untuk kurva himpunan keanggotaan tinggi menggunakan rumus kurva linier naik (1). Hasil tes kompetensi pedagogik dari 18 calon guru diperoleh nilai minimal adalah 51 dan nilai maksimalnya adalah 86 . Diperoleh nilai tengah dari 51 dan 86 adalah $(51+86) / 2=68,5$. Diperoleh nilai input untuk untuk kompotensi pedagogik, yaitu: rendah $[0,51,68,5]$; sedang $[51,68,5,86]$; dan tinggi $[68,5,86,100]$. Representasi grafik fungsi keanggotaan kompetensi pedagogik dapat dilihat pada Gambar 7.

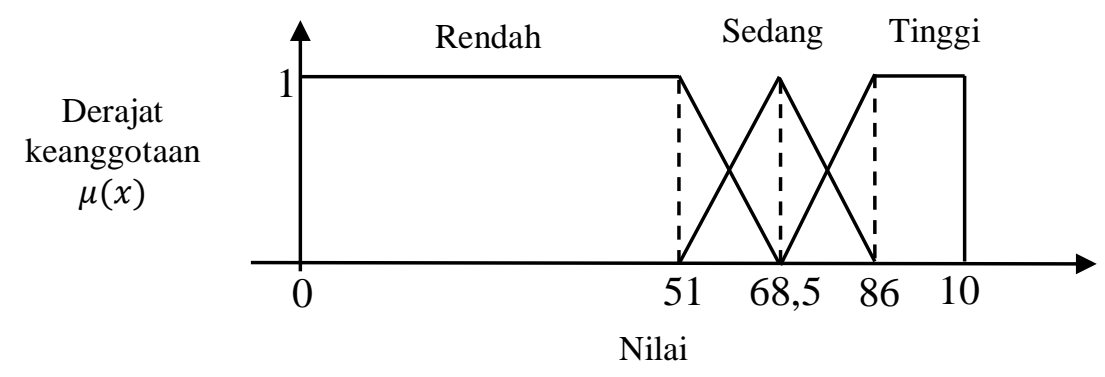

Gambar 7. Representasi Grafik Fungsi Keanggotaan Kompetensi Pedagogik

Rumus fungsi yang digunakan untuk menyatakan derajat keanggotaan dari variabel kompetensi pedagogik sebagai berikut. 


$$
\begin{aligned}
& \mu_{\text {rendah }}(x)=\left\{\begin{array}{cc}
1 & x \leq 51 \\
\frac{(68,5-x)}{(68,5-51)} & 51 \leq x \leq 68,5 \\
0 & x \geq 68,5
\end{array}\right. \\
& \mu_{\text {sedang }}(x)=\left\{\begin{array}{cc}
0 & x \leq 51 \text { atau } x \geq 86 \\
\frac{(x-51)}{(68,5-51)} & 51 \leq x \leq 68,5 \\
\frac{(86-x)}{(86-68,5)} & 68,5 \leq x \leq 86
\end{array}\right. \\
& \mu_{\text {tinggi }}(x)=\left\{\begin{array}{cc}
0 & x \leq 68,5 \\
\frac{(x-68,5)}{(86-68,5)} & 68,5 \leq x \leq 86 \\
1 & x \geq 86
\end{array}\right.
\end{aligned}
$$

\subsubsection{Fungsi Keanggotaan Kompetensi Profesional}

Pada variabel output Kompetensi Profesional (KPr) didefinisikan tiga himpunan Fuzzy, yaitu rendah, sedang, dan tinggi. Representasi kurva untuk himpunan keanggotaan rendah menggunakan rumus fungsi kurva linier turun (2), representasi kurva untuk himpunan keanggotaan sedang menggunakan rumus fungsi kurva segitiga (3), sedangkan representasi untuk kurva himpunan keanggotaan tinggi menggunakan rumus fungsi kurva naik (1). Hasil tes kompetensi profesional dari 18 calon guru diperoleh nilai minimal adalah 36 dan nilai maksimalnya adalah 72 . Diperoleh nilai tengah dari 36 dan 72 adalah $(36+72) / 2=54$. Diperoleh nilai input untuk untuk kompotensi profesional, yaitu: rendah [0, 36, 54]; sedang [36, 54, 72]; dan tinggi $[54,72,100]$. Representasi grafik fungsi keanggotaan kompetensi profesional dapat dilihat pada Gambar 8 .

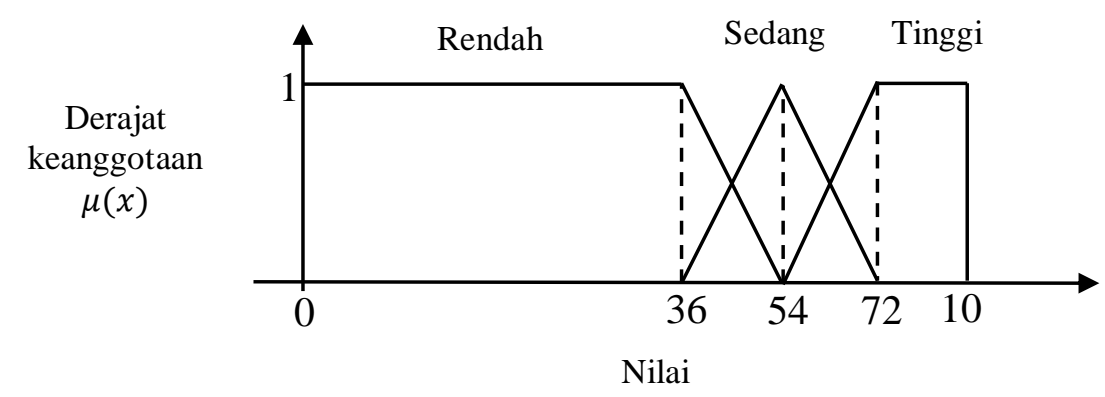

Gambar 8. Representasi Grafik Fungsi Keanggotaan Kompetensi Profesional

Rumus fungsi yang digunakan untuk menyatakan derajat keanggotaan dari variabel kompetensi profesional sebagai berikut.

$$
\begin{aligned}
& \mu_{\text {rendah }}(x)=\left\{\begin{array}{cc}
1 & x \leq 36 \\
\frac{(54-x)}{(54-36)} & 36 \leq x \leq 54 \\
0 & x \geq 54
\end{array}\right. \\
& \mu_{\text {sedang }}(x)=\left\{\begin{array}{cc}
0 & x \leq 36 \text { atau } x \geq 72 \\
\frac{(x-36)}{(54-36)} & 36 \leq x \leq 54 \\
\frac{(72-x)}{(72-54)} & 54 \leq x \leq 72
\end{array}\right.
\end{aligned}
$$




$$
\mu_{\text {tinggi }}(x)=\left\{\begin{array}{cc}
0 & x \leq 54 \\
\frac{(x-54)}{(72-54)} & 54 \leq x \leq 72 \\
1 & x \geq 72
\end{array}\right.
$$

\subsection{Desain Program Fuzzifikasi Tahani}

Tahap kedua penelitian ini adalah mendesain program Fuzzifikasi Tahani dengan menggunakan program microsoft excel. Ada 4 desain program Fuzifikasi Tahani dengan Microsoft Excel, yaitu (1) membuat desain program penilaian kompetensi, (2) membuat desain program derajat keanggotan dari masing-masing variabel input, (3) membuat fuzifikasi keanggotaan dari semua variabel output, dan (4) membuat desain rekomendasi keputusan. Masing-masing hasil desain adalah berikut ini.

\subsubsection{Desain Program Penilaian Kompetensi}

Desain program penilaian kompetensi berdasarkan banyaknya soal pada masing-masing tes kompetensi guru. Secara umum untuk mendapatkan nilai dari masing-masing kompetensi menggunakan rumus berikut.

$$
\text { Nilai Kompetensi }=\frac{\text { Total menjawab benar }}{\text { banyaknya soal }} \times 100
$$

Dengan menggunakan rumus (17) maka desain program penilaian dari masing-masing kompetensi dengan menggunakan microsoft excel dapat dilihat pada Tabel 1.

Tabel 1. Desain Penilaian Kompetensi

\begin{tabular}{|cccccccccc|}
\hline \multirow{2}{*}{ No. } & \multirow{2}{*}{ Nama Peserta Tes } & \multicolumn{8}{c|}{ Nilai Uji Kompetensi } \\
\cline { 3 - 9 } & & \multicolumn{2}{c|}{ Kepribadian } & \multicolumn{2}{c|}{ Sosial } & Pedagogik & \multicolumn{2}{c|}{ Profesional } \\
\cline { 3 - 9 } & Benar & Nilai & Benar & Nilai & Benar & Nilai & Benar & Nilai \\
\hline 1 & Nizar Agung Siswahyudi, S.Pd. & 12 & 80 & 13 & 87 & 28 & 80 & 18 & 72 \\
2 & $\ldots$ & 0 & 0 & 0 & 0 & 0 & 0 & 0 & 0 \\
3 & $\ldots$ & 0 & 0 & 0 & 0 & 0 & 0 & 0 & 0 \\
$\ldots$ & $\ldots$ & 0 & 0 & 0 & 0 & 0 & 0 & 0 & 0 \\
\hline
\end{tabular}

Langkah kerja pada Tabel 1 adalah dengan menuliskan nama peserta tes, kemudian memasukkan total jawaban yang benar pada masing-masing skor kompetensi. Secara otomatis nilai akan muncul untuk masingmasing kompetensi.

\subsubsection{Desain Program Derajat Keanggotaan Masing-Masing Kompetensi}

Desain program yang kedua adalah program derajat keanggotaan dari masing-masing kompetensi. Derajat keanggotaan dari kompetensi kepribadian terdiri dari rendah, sedang, dan tinggi. Program untuk derajat keanggotaan rendah menggunakan rumus (5), untuk derajat keanggotaan sedang menggunakan rumus (6), dan derajat keanggotaan tinggi menggunakan rumus (7). Diperoleh program microsoft excel untuk menentukan derajat keanggotaan dari kompetensi kepribadian dapat dilihat dalam Tabel 2.

Tabel 2. Desain Program Derajat Keanggotaan Kompetensi Kepribadian

\begin{tabular}{|ccccccc|}
\hline \multirow{2}{*}{ No. } & & \multirow{2}{*}{ Nama Peserta Tes } & Nilai Kompetensi & \multicolumn{3}{c|}{ Derajat Keanggotaan } \\
\cline { 4 - 6 } & & Kepribadian & Rendah & Sedang & Tinggi \\
\hline 1 & Nizar Agung Siswahyudi, S.Pd. & 80 & 0,0000 & 0,7000 & 0,3000 \\
2 & $\ldots$ & 0 & 1,0000 & 0,0000 & 0,0000 \\
3 & $\ldots$ & 0 & 1,0000 & 0,0000 & 0,0000 \\
$\ldots$ & $\ldots$ & 0 & 1,0000 & 0,0000 & 0,0000 \\
\hline
\end{tabular}

Derajat keanggotaan dari kompetensi sosial untuk derajat keanggotaan rendah menggunakan rumus (8), untuk derajat keanggotaan sedang dari kompetensi sosial menggunakan rumus (9), dan derajat keanggotaan tinggi dari kompetensi sosial menggunakan rumus (10). Diperoleh program microsoft excel untuk menentukan derajat keanggotaan dari kompetensi sosial dapat dilihat dalam Tabel 3. 
Tabel 3. Desain Program Derajat Keanggotaan Kompetensi Sosial

\begin{tabular}{|crrcccc|}
\multirow{2}{*}{ No. } & & \multirow{2}{*}{ Nama Peserta Tes } & Nilai Kompetensi & \multicolumn{3}{c|}{ Derajat Keanggotaan } \\
\cline { 4 - 7 } & & Sosial & Rendah & Sedang & Tinggi \\
\hline 1 & \multirow{2}{*}{ Nizar Agung Siswahyudi, S.Pd. } & 87 & 0,0000 & 0,4872 & 0,5128 \\
2 & $\ldots$ & 0 & 1,0000 & 0,0000 & 0,0000 \\
3 & $\ldots$ & 0 & 1,0000 & 0,0000 & 0,0000 \\
$\ldots$ & $\ldots$ & 0 & 1,0000 & 0,0000 & 0,0000 \\
\hline
\end{tabular}

Derajat keanggotaan rendah dari kompetensi pedagogik dibangun dengan menggunakan rumus (11), untuk derajat keanggotaan sedang menggunakan rumus (12), dan derajat keanggotaan tinggi menggunakan rumus (13). Diperoleh program microsoft excel untuk menentukan derajat keanggotaan dari kompetensi pedagogik dapat dilihat dalam Tabel 4.

Tabel 4. Desain Program Derajat Keanggotaan Kompetensi Pedagogik

\begin{tabular}{|crccccc|}
\hline \multirow{2}{*}{ No. } & & \multirow{2}{*}{ Nama Peserta Tes } & Nilai Kompetensi & \multicolumn{3}{c|}{ Derajat Keanggotaan } \\
\cline { 4 - 6 } & & Pedagogik & Rendah & Sedang & Tinggi \\
\hline 1 & Nizar Agung Siswahyudi, S.Pd. & 80 & 0,0000 & 0,3429 & 0,6571 \\
2 & $\ldots$ & 0 & 1,0000 & 0,0000 & 0,0000 \\
3 & $\ldots$ & 0 & 1,0000 & 0,0000 & 0,0000 \\
$\ldots$ & $\ldots$ & 0 & 1,0000 & 0,0000 & 0,0000 \\
\hline
\end{tabular}

Derajat keanggotaan rendah dari kompetensi profesional dibangun dengan menggunakan rumus (14), untuk derajat keanggotaan sedang menggunakan rumus (15), dan derajat keanggotaan tinggi menggunakan rumus (16). Diperoleh program microsoft excel untuk menentukan derajat keanggotaan dari kompetensi profesional dapat dilihat dalam Tabel 5.

Tabel 5. Desain Program Derajat Keanggotaan Kompetensi Profesional

\begin{tabular}{|crccccc|}
\hline \multirow{2}{*}{ No. } & & \multirow{2}{*}{ Nama Peserta Tes } & Nilai Kompetensi & \multicolumn{3}{c|}{ Derajat Keanggotaan } \\
\cline { 4 - 6 } & & Profesional & Rendah & Sedang & Tinggi \\
\hline 1 & Nizar Agung Siswahyudi, S.Pd. & 72 & 0,0000 & 0,0000 & 1,0000 \\
2 & $\ldots$ & 0 & 1,0000 & 0,0000 & 0,0000 \\
3 & $\ldots$ & 0 & 1,0000 & 0,0000 & 0,0000 \\
$\ldots$ & $\ldots$ & 0 & 1,0000 & 0,0000 & 0,0000 \\
\hline
\end{tabular}

Cara kerja program derajat keanggotaan dari kompetensi kepribadian, sosial, pedagogik, dan profesional mengikuti penilaian kompetensi kepribadian, sosial, pedagogik, dan profesional (lihat Tabel 1). Setelah nilai dimasukkan pada bagian nilai kompetensi, secara otomatis akan muncul penghitungan derajat keanggotaan nilai kompetensi kepribadian, derajat keanggotaan nilai kompetensi sosial, derajat keanggotaan nilai kompetensi pedagogik, dan derajat keanggotaan nilai kompetensi profesional.

\subsubsection{Desain Program Rekomendasi Keputusan}

Program fuzifikasi yang ketiga adalah desain program rekomendasi keputusan. Desain rekomendasi keputusan dapat dilihat pada Tabel 6.

Tabel 6. Desain Rekomendasi Keputusan

\begin{tabular}{|c|c|c|c|c|c|c|}
\hline \multirow{3}{*}{ No. } & \multirow{3}{*}{ Nama Peserta Tes } & \multicolumn{4}{|c|}{ Derajat Keanggotaan Nilai Kompetensi } & \multirow{3}{*}{$\begin{array}{l}\text { Rekomendas } \\
\text { Keputusan }\end{array}$} \\
\hline & & Kepribadian & Sosial & Pedagogik & Profesional & \\
\hline & & Tinggi & Tinggi & Tinggi & Tinggi & \\
\hline 1 & Nizar Agung Siswahyudi, S.Pd. & 0,3000 & 0,5128 & 0,6571 & 1,0000 & 0,5425 \\
\hline 2 & $\ldots$ & 0,0000 & 0,0000 & 0,0000 & 0,0000 & 0,0000 \\
\hline 3 & $\ldots$ & 0,0000 & 0,0000 & 0,0000 & 0,0000 & 0,0000 \\
\hline$\ldots$ & $\ldots$ & 0,0000 & 0,0000 & 0,0000 & 0,0000 & 0,0000 \\
\hline
\end{tabular}

Cara kerja rekomendasi keputusan pada Tabel 6 adalah secara otomatis akan sesuai dengan pengisian derajat keanggotaan pada tahapan desain derajat keanggotaan masing-masing kompetensi. Rekomendasi ini dibuat dengan ketentuan derajat keanggotaan kompetensi kepribadian = 'Tinggi', Sosial = 'Tinggi', Pedagogik $=$ 'Tinggi', Profesional $=$ 'Tinggi'. Kemudian nilai rekomendasi dieksekusi menggunakan 
Structure Query Language (SQL), yaitu (Kepribadian + Sosial + Pedagogik + Profesional)/4 = rekomendasi keputusan.

\subsection{Implementasi Desain Program Fuzifikasi Tahani}

Tahap ketiga adalah mengimplementasikan hasil desain program fuzifikasi tahani untuk pengambilan keputusan tiga guru matematika yang akan direkomendasikan untuk direkrut sebagai guru di MTs Darun Najah Lumajang. Langkah pertama adalah menentukan nilai tes kompetensi dari calon guru dengan cara memasukkan total jawaban yang benar ke program yang berhasil dibuat seperti yang dapat dilihat dalam Tabel 7.

Tabel 7. Nilai Tes Uji Kompetensi Guru

\begin{tabular}{|c|c|c|c|c|c|c|c|c|c|}
\hline \multirow{3}{*}{ No. } & \multirow{3}{*}{ Nama Peserta Tes } & \multicolumn{8}{|c|}{ Nilai Uji Kompetensi } \\
\hline & & \multicolumn{2}{|c|}{ Kepribadian } & \multicolumn{2}{|c|}{ Sosial } & \multicolumn{2}{|c|}{ Pedagogik } & \multicolumn{2}{|c|}{ Profesional } \\
\hline & & Benar & Nilai & Benar & Nilai & Benar & Nilai & Benar & Nilai \\
\hline 1 & Nizar Agung Siswahyudi, S.Pd. & 12 & 80 & 13 & 87 & 28 & 80 & 18 & 72 \\
\hline 2 & Aliyatul Fikriyah, S.Pd. & 11 & 73 & 10 & 67 & 25 & 71 & 15 & 60 \\
\hline 3 & Miftahul Jannah, S.Pd. & 12 & 80 & 12 & 80 & 27 & 77 & 13 & 52 \\
\hline 4 & Aprilia Wulandari, S.Pd. & 13 & 87 & 14 & 93 & 25 & 71 & 18 & 72 \\
\hline 5 & Zainal Naili Su’ad, S.Pd. & 12 & 80 & 13 & 87 & 26 & 74 & 12 & 48 \\
\hline
\end{tabular}

Dari Tabel 7 dapat dilihat bahwa implementasi desain program fuzzifikasi Tahani dengan input banyaknya jawaban benar dan secara otomatis akan muncul nilai dari masing-masing uji kompetensi dengan menggunakan rumus perhitungan (17). Misalnya jawaban benar kompetensi kepribadian adalah 12, maka nilai untuk kompetensi kepribadian adalah $\frac{12}{15} \times 100=0,8 \times 100=80$ (dimana 15 adalah banyaknya soal).

Langkah kedua adalah melakukan fuzifikasi dari nilai yang diperoleh calon guru. Fuzifikasi yaitu menentukan derajat keanggotaan dari nilai kompetensi dari masing-masing guru yang terdiri dari kompetensi kepribadian, kompetensi sosial, kompetensi pedagogik, dan kompetensi profesional. Derajat keanggotaan dari keempat kompetensi ini secara otomatis akan terisi sendiri. Contoh derajat keanggotaan dari nilai kompetensi guru dapat dilihat pada Tabel 8.

Tabel 8. Derajat Keanggotaan Dari Nilai Uji Kompetensi Guru

\begin{tabular}{|c|c|c|c|c|c|c|c|c|c|c|c|c|c|}
\hline \multirow{3}{*}{ No. } & \multirow{3}{*}{ Nama Peserta Tes } & \multicolumn{12}{|c|}{ Fuzifikasi Nilai Uji Kompetensi } \\
\hline & & \multicolumn{3}{|c|}{ Kepribadian } & \multicolumn{3}{|c|}{ Sosial } & \multicolumn{3}{|c|}{ Pedagogik } & \multicolumn{3}{|c|}{ Profesional } \\
\hline & & $\mathbf{R}$ & $\mathbf{S}$ & $\mathbf{T}$ & $\mathbf{R}$ & $\mathbf{S}$ & $\mathbf{T}$ & $\mathbf{R}$ & $\mathbf{S}$ & $\mathbf{T}$ & $\mathbf{R}$ & $\mathbf{S}$ & $\mathbf{T}$ \\
\hline 1 & Nizar Agung S., S.Pd. & 0,0000 & 0,7000 & 0,3000 & 0,0000 & 0,4872 & 0,5128 & 0,0000 & 0,3429 & 0,6571 & 0,0000 & 0,0000 & 1,0000 \\
\hline 2 & Aliyatul Fikriyah, S.Pd. & 0,3667 & 0,6333 & 0,0000 & 1,0000 & 0,0000 & 0,0000 & 0,0000 & 0,8327 & 0,1673 & 0,0000 & 0,6667 & 0,3333 \\
\hline 3 & Miftahul Jannah, S.Pd. & 0,0000 & 0,7000 & 0,3000 & 0,0000 & 1,0000 & 0,0000 & 0,0000 & 0,5061 & 0,4939 & 0,1111 & 0,8889 & 0,0000 \\
\hline 4 & Aprilia Wulandari, S.Pd. & 0,0000 & 0,0333 & 0,9667 & 0,0000 & 0,0000 & 1,0000 & 0,0000 & 0,8327 & 0,1673 & 0,0000 & 0,0000 & 1,0000 \\
\hline 5 & Zainal Naili Su'ad, S.Pd. & 0,0000 & 0,7000 & 0,3000 & 0,0000 & 0,4872 & 0,5128 & 0,0000 & 0,6694 & 0,3306 & 0,3333 & 0,6667 & 0,0000 \\
\hline
\end{tabular}

Dari Tabel 8 dapat dilihat bahwa dari masing-masing nilai uji kompetensi akan ditentukan derajat keanggotaanya dengan menggunakan rumus fungsi derajat keanggotaan. Misalnya nilai kompetensi kepribadian adalah 80, maka derajat keanggotaannya dari kategori rendah adalah 0,000 karena $80 \geq 77$ (lihat rumus (3)), derajat keanggotaan untuk kategori sedang adalah $\frac{(87-80)}{87-77}=\frac{7}{10}=0,7000$, karena $77 \leq 80 \leq 87$ (lihat rumus (6)), dan derajat keanggotaan untuk kategori tinggi adalah $\frac{(80-77)}{87-77}=\frac{3}{10}=0,3000$, karena $77 \leq$ $80 \leq 87$ (lihat rumus (7)).

Langkah ketiga adalah menentukan rekomendasi pengambilan keputusan. Rekomendasi keputusan ini secara otomatis akan muncul dalam program yang telah dibuat di tahap kedua. Urutan rekomendasi pengambilan keputusan untuk penerimaan guru dapat dilihat dalam Tabel 9. 
Tabel 9. Rekomendasi Pengambilan Keputusan untuk Perekrutan Guru

\begin{tabular}{|c|c|c|c|c|c|c|}
\hline \multirow{3}{*}{ No. } & \multirow{3}{*}{ Nama Peserta Tes } & \multicolumn{4}{|c|}{ Derajat Keanggotaan Nilai Kompetensi } & \multirow{3}{*}{$\begin{array}{c}\text { Rekomendasi } \\
\text { Keputusan }\end{array}$} \\
\hline & & Kepribadian & Sosial & Pedagogik & Profesional & \\
\hline & & Tinggi & Tinggi & Tinggi & Tinggi & \\
\hline 1 & Nizar Agung Siswahyudi, S.Pd. & 0.3000 & 0.5128 & 0.6571 & 1.0000 & 0.6175 \\
\hline 2 & Aliyatul Fikriyah, S.Pd. & 0.0000 & 0.0000 & 0.1673 & 0.3333 & 0.1252 \\
\hline 3 & Miftahul Jannah, S.Pd. & 0.3000 & 0.0000 & 0.4939 & 0.0000 & 0.1985 \\
\hline 4 & Aprilia Wulandari, S.Pd. & 0.9667 & 1.0000 & 0.1673 & 1.0000 & 0.7835 \\
\hline 5 & Zainal Naili Su'ad, S.Pd. & 0.3000 & 0.5128 & 0.3306 & 0.0000 & 0.2859 \\
\hline 6 & Faiqotuz Zainiyah, S.Pd.I & 0.0000 & 0.0000 & 0.0000 & 0.0000 & 0.0000 \\
\hline 7 & Siti Lulhkiyah, S.Pd. & 0.3000 & 0.0000 & 0.0000 & 0.0000 & 0.0750 \\
\hline 8 & Maghfirotul Khasanah, S.Pd. & 0.9667 & 0.0000 & 0.0041 & 0.1111 & 0.2705 \\
\hline 9 & Uswatun Hasanah, S.Pd. & 0.3000 & 0.0000 & 0.1673 & 0.7778 & 0.3113 \\
\hline 10 & Hadid Afiat Imansyah, S.Pd. & 0.3000 & 0.0000 & 0.6571 & 0.5556 & 0.3782 \\
\hline 11 & Evi Fitri Rachmayani, S.Pd. & 0.0000 & 0.0000 & 0.0000 & 0.3333 & 0.0833 \\
\hline 13 & Ifni Lusiana Devi, S.Pd. & 0.3000 & 0.0000 & 0.3306 & 0.5556 & 0.2965 \\
\hline 14 & Neal Ajie, ST. & 0.9667 & 0.0000 & 0.1673 & 0.7778 & 0.4779 \\
\hline 15 & Abdul Halim, S.Pd.I & 0.3000 & 0.0000 & 0.0000 & 0.0000 & 0.0750 \\
\hline 16 & Imam Wahyudi, S.Pd.I & 0.0000 & 0.0000 & 0.0000 & 0.0000 & 0.0000 \\
\hline 17 & Dia Retno Purwaningrum, S.Pd. & 0.3000 & 0.0000 & 0.9837 & 0.3333 & 0.4043 \\
\hline 18 & Miftahul Huda, S.Pd. & 0.0000 & 0.0000 & 0.0000 & 0.0000 & 0.0000 \\
\hline
\end{tabular}

Sesuai dengan kebutuhan guru di MTs Darun Najah, maka guru yang direkomendasikan adalah yang memiliki derajat rekomendasi tertinggi diantara 18 orang yang mengikuti tes rekrutmen guru, yaitu: Aprilia Wulandari, S.Pd., Nizar Agung Siswahyudi, S.Pd., dan Neal Ajie, ST. Selain itu juga terlihat dalam Tabel 5 bahwa derajat keanggotaan dari masing-masing kompetensi yang berada pada kategori tinggi dari peserta nomor 1 dan 4 terpenuhi semua. Bisa diartikan bahwa peserta nomor 1 dan 4 ini memiliki nilai kompetensi yang tinggi untuk masing-masing kompetensi guru. Jadi untuk itulah, peneliti merekomendasikan untuk peserta nomor 1 dan 4. Sedangkan untuk peserta nomor 14 direkomendasikan karena memiliki derajat rekomendasi tinggi diantara peserta selain nomor 1 dan 4 .

Perbandingan hasil implementasi fuzzy Tahani dengan hasil rata-rata yang diperoleh oleh guru dapat dilihat dalam Tabel 10.

Tabel 10. Perbandingan Hasil Implementasi Fuzzy Tahani dengan Rata-rata Nilai

\begin{tabular}{|c|c|c|c|c|c|c|c|}
\hline No. & Nama Peserta Tes & $\begin{array}{l}\text { Nilai } \\
\text { Kep. }\end{array}$ & $\begin{array}{l}\text { Nilai } \\
\text { Sos. }\end{array}$ & $\begin{array}{l}\text { Nilai } \\
\text { Ped. }\end{array}$ & $\begin{array}{l}\text { Nilai } \\
\text { Prof. }\end{array}$ & $\begin{array}{c}\text { Rata- } \\
\text { rata }\end{array}$ & $\begin{array}{c}\text { Hasil } \\
\text { Fuzifikasi }\end{array}$ \\
\hline 1 & Aprilia Wulandari, S.Pd. & 87 & 93 & 71 & 72 & 80.86 & 0.7835 \\
\hline 2 & Nizar Agung Siswahyudi, S.Pd. & 80 & 87 & 80 & 72 & 79.67 & 0.6175 \\
\hline 3 & Dia Retno Purwaningrum, S.Pd. & 80 & 80 & 86 & 60 & 76.43 & 0.4043 \\
\hline 4 & Neal Ajie, ST. & 87 & 73 & 71 & 68 & 74.86 & 0.4779 \\
\hline 5 & Ifni Lusiana Devi, S.Pd. & 80 & 80 & 74 & 64 & 74.57 & 0.2965 \\
\hline 6 & $\ldots$ & & & & & & \\
\hline
\end{tabular}

Dari Tabel 10 dapat diketahui bahwa perbandingan untuk peringkat pertama dan kedua telah sesuai antara rata-rata dengan hasil fuzifikasi menggunakan fuzzy Tahani. Sedangkan hasil untuk peringkat ketiga dan keempat terdapat perbedaan. Dimana rata-rata hasil tes kompetensi peringkat keempat lebih tinggi daripada peserta perigkat ketiga, sedangkan hasil fuzifikasi menunjukkan bahwa peserta tes dengan peringkat ketiga lebih tinggi daripada peserta tes dengan peringkat keempat. Perbedaan ini disebabkan karena peserta pada peringkat ketiga memiliki derajat keanggotaan dengan kategori tinggi pada tiga kompetensi, sedangkan peserta peringkat keempat hanya memiliki derajat keanggotaan dengan kategori tinggi pada satu kompetensi. Hasil penelitian ini telah menunjukkan bahwa pengambilan keputusan penerimaan guru yang memiliki empat kompetensi secara menyeluruh dapat menggunakan teori fuzzy tahani. Ini juga dapat dikatakan bahwa implementasi teori fuzzy Tahani lebih baik daripada hanya berdasarkan rata-rata, karena teori fuzzy Tahani lebih adil dalam mempertimbangkan berbagai kriteria-kriteria. Hasil penelitian ini sesuai dengan hasil penelitian sebelumnya juga menunjukkan bahwa logika Fuzzy Tahani dapat digunakan sebagai sistem 
pendukung kenaikan jabatan yang efektif dan efisien [16][17], serta sebagai sistem pendukung untuk menilai kinerja secara efisien daripada secara manual [14][12].

\section{KESIMPULAN}

Hasil penelitian ini telah menunjukkan bahwa implementasi logika fuzzy Tahani untuk sistem pendukung pengambilan keputusan perekrutan guru dapat digunakan. Karena sistem pendukung pengambilan keputusan dengan menggunakan logika fuzzy tahani adalah mempertimbangkan kriteria-kriteria secara menyeluruh. Jadi peneliti merekomendasikan untuk menerapkan fuzzy tahani sebagai sistem pendukung pengambilan keputusan yang melibatkan berbagai kriteria.

\section{DAFTAR PUSTAKA}

[1] G. Taufiq, "Logika Fuzzy Tahani untuk Pendukung Keputusan Perekrutan Karyawan Tetap," Pros. Semin. Nas. Apl. Sains Teknol., no. November, pp. 99-106, 2014.

[2] R. Inayah, T. Martono, and H. Sawiji, "Pengaruh Kompetensi Guru, Motivasi Belajar Siswa, dan Fasilitas Belajar terhadap Prestasi Belajar Mata Pelajaran Ekonomi pada Siswa Kelas XI IPS SMA Negeri 1 Lasem Jawa Tengah Tahun Pelajaran 2011/2012," Jurnal Pendidikan Insan Mandiri, vol. 1, no. 1. pp. 1-13, 2013.

[3] Y. E. Setiawan, "Analisis Domain dan Dampak Mathematical Knowledge for Teaching Terhadap Pengajaran," in Reformasi Pendidikan dalam Memasuki ASEAN Economic Community (AEC), 2015, pp. 1263-1271.

[4] Y. E. Setiawan, "The Thinking Process of Students Using Trial and Error Strategies in Generalizing Linear Patterns," Numer. J. Mat. dan Pendidik. Mat., vol. 4, no. 1, pp. 1-12, 2020.

[5] Y. E. Setiawan and Syaifuddin, "Peningkatan Kompetensi Profesionalitas Guru Melalui Pelatihan Desain Pembelajaran Peta Konsep," J. Pengabdi. Kpd. Masy., vol. 26, no. 3, pp. 148-153, 2020.

[6] Y. E. Setiawan, Purwanto, I. N. Parta, and Sisworo, "Generalization Strategy of Linear Patterns From FieldDependent Cognitive Style," J. Math. Educ., vol. 11, no. 1, pp. 77-94, 2020.

[7] Y. E. Setiawan, "Analisis Kesalahan Siswa dalam Menilai Kebenaran Suatu Pernyataan," J. Didakt. Mat., vol. 7, no. 1, pp. 13-31, 2020.

[8] Y. E. Setiawan, "Analisis Kemampuan Siswa dalam Pembuktian Kesebangunan Dua Segitiga," Al-Khwarizmi J. Pendidik. Mat. dan Ilmu Pengetah. Alam, vol. 8, no. 1, pp. 23-38, 2020.

[9] Y. E. Setiawan and Mustangin, "Validitas Model Pembelajaran IDEA ( Issue, Discussion, Establish, and Apply) untuk Meningkatkan Pemahaman Konsep," J. Penelit. Pendidik. dan Pengajaran Mat., vol. 6, no. 1, pp. 53-60, 2020.

[10] G. Taufiq, "Implementasi Logika Fuzzy Tahani Untuk Model Sistem Pendukung Keputusan Evaluasi Kinerja Karyawan," J. Pilar Nusa Mandiri, vol. 12, no. 1, pp. 12-20, 2016.

[11] A. Rusman, "Logika Tuzzy Tahani Sistem Penunjang Keputusan Penentuan Lulusan Terbaik," J. Inform., vol. 3, no. 1, pp. 31-40, 2016.

[12] M. Susanti, "Sistem Penunjang Keputusan Untuk Penilaian Guru Menggunakan Model Logika Fuzzy Tahani," Swabumi, vol. 5, no. 1, pp. 90-98, 2017.

[13] M. Asrori and A. Z. Falani, "Implementasi Penentuan Pemberian Tunjangan Pendidik \& Tenaga Kependidikan Berbasis Fuzzy Database Model Tahani,” J. Insa. Comtech, vol. 4, no. 2, pp. 19-25, 2019.

[14] A. Maulana, Y. V. Via, and L. P. Purba, "Penilaian Kinerja Dosen Menggunakan Fuzzy Tahani Berdasarkan Kuisioner Evaluasi Belajar Mengajar,” SCAN, vol. 10, no. 3, pp. 53-60, 2015.

[15] Safrizal and Susianto, "Pengembangan Model Sistem Pendukung Keputusan Dengan Kombinasi Metode Fuzzy Tahani Dan Topsis Dalam Penilaian Kinerja Instruktur," J-SAKTI (Jurnal Sains Komput. dan Inform., vol. 3, no. 2, pp. 227-242, 2019.

[16] F. A. Sianturi, R. F. Siahaan, and A. Fitra, "Penerapan Metode Fuzzy Model Tahani Dalam Sistem Pendukung Keputusan Kenaikan Jabatan,” InfoTekJar J. Nas. Inform. dan Teknol. Jar., vol. 4, no. 2, pp. 85-90, 2020.

[17] D. Abdullah, H. Djanggih, S. Suendri, H. Cipta, and N. Nofriadi, "Fuzzy Model Tahani as Decision Support System for Employee Promotion," Int. J. Eng. Technol., vol. 7, no. 2.5, pp. 88-91, 2018. 
